working below $1^{\circ} \mathrm{K}$. which had been established in Oxford by 1939. When the War came he joined the Admiralty research team at Oxford, and in 1941 designed and constructed what was probably the first continuous-wave escillator in the millimetre region. As the War progressed he became more and more occupied with the training of physicists, who were required in ever-growing numbers. His very considerable administrative abilities now became apparent, both in the organisation of teaching and elsewhere in the Laboratory. In 1944 he spent a term as a visiting professor at Harvard University, assisting in the U.S. Navy's radio training scheme, and in the same year he was elected a fellow of Brasenose College. In 1948 he became a member of the General Board of the Faculties and was soon an accepted and vigorous representative of the science faculties.

Any problem Hull took up was considered long and deeply. When his mind was made up, he would speak it even though it meant saying the difficult and unpopular thing. Something of this same deliberate quality was the secret of his success as a teacher and a man of science. He would never willingly accept a partial solution. Many brought their problems to him and found him very generous of time and trouble in helping them. Above all was his sincerity and reliability : what he said, he meant, and what he promised, he did.

Though perhaps too reserved for more than a few to know him intimately, he found many friends not only in the learned faculties but also in a wide range of University life from the hockey field to the Bach Choir and the Music Club. An experienced mountaineer and an expert photographer, he was never happier than when among the hills either in Britain or in the Alps. Even on the wettest and coldest of days, it was always good fun to be with him there.

In 1937 Hull married Miss Judith Moore, like him. self a research worker in the Clarendon Laboratory. She died in 1943. They leave one daughter.

J. WILKS

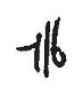

Pituitary Adrenocorticotropin : Research at Cam-
bridge

THE hormone of the anterior pituitary lobe has excited great interest oyer the past twenty-five years, and although results of the greatest theoretical significance hav fecrued from the large amount of research carried fut on this subject, little of practical importance hasis developed therefrom until recently. Within he pust year, interest has been particularly dipectpd to the adrenocorticotropic hormone of the antride pituitary gland for two reasons. First, as would be expected from the action of cortisone, adrenocorticotropin is effective in the treatment of rheumatoid arthritis. Secondly, Li and others have shown that the biological activity of adrenocorticotropin can be retained during the degradation of this protein hormone to a moderately sized peptide. The synthesis of such a peptide, the activity of which would be of the greatest interest in practical medicine, is therefore within the realm of possibility.

The Nuffield Foundation, whose support of research on rheumatism is of many years standing, has not been slow to realize the significance of this position, and the Trustees have recently made an offer to the University of Cambridge, which has been accepted, to provide a grant of $£ 11,000$, spread over three years, to support research on adrenocorticotiopin in the School of Biochemistry under the direction of Prof. F. G. Young. For the past fifteen years, Prof. Young has been pursuing research on the relationship of anterior pituitary hormones to metabolic processes with particular reference to diabetes, and has recently identified one diabetogenic pituitary substance with the growth hormone. As has been demonstrated in the United States by Li, Conn and others, pituitary adrenocorticotropic hormone can also be diabetogenic in some species. In Great Britain, however, research of this type has always been hampered by the poor supply of active material, and with the support of the Nuffield Foundation Prof. Young will be able to prepare substantial quantities of adrenocorticotropic hormone, and to pursue investigations, which would otherwise not have been possible, on the structure of the hormone itself and of derived pep. tides. The hope that this work may provide a basis for an attack on the synthesis of active substances is a real one, and in this aspect of the work Prof. A. R. Todd and his staff, in the University Chemical Laboratories at Cambridge, are prepared to collab. orate with Prof. Young and his team, also with the support of the Nuffield Foundation.

\section{Trotter and Paterson Memorial Lectures of the Illuminating Engineering Society}

THE Council of the Illuminating Engineering Society is raisinga fund to provide for public lectures in memory of the late Mr. A. P. Trotter and the late Sir Clifford/Paterson. It has been suggested that the money should be contributed in small sums from the whole membership of the Society, and that the intergst on the capital be used to provide fees for the lecturers. The cost of the meetings and of the publication of the lectures in the Transactions of the Society will be borne by the Society out of its general income. The lectures will be given alternately as the Trotter Memorial and the Paterson Memorial at intervals which will depend on the response to this appeal, and they will take place, in the first instance, in London and will be repeated in the Provinces, if appropriate. The subjects of the first few lectures will be related to the particular interests of $\mathrm{Mr}$. Trotter and of Sir Clifford Paterson; but later lectures will be of a more general character, dealing with pioneer work or with some broad review of developments or knowledge.

Mr. Trotter's association with lighting was unique (see Nature, 160, 390; 1947). More than sixty years ago he was a pioneer in photometry, public lighting and vision under conditions of low illumination, and as president of the Society during the First World War he paved the way for collaboration between the lighting industry and the Government. In the Board of Trade he contributed largely to the Electricity Regulations, and as editor of the Electrician he had a considerable influence on the growth of the industry. Sir Clifford Paterson also made a very personal con. tribution to the science and industry of illumination (see Nature, 162, 325; 1948). His connexion with 
the lighting industry started in 1903 at the National Physical Laboratory, where he was largely responsible for the design and calibration of the electric lamps which formed the standard of luminous intensity until 1948. Sir Clifford was, for a number of years, the director of the Research Laboratories of the General Electric Co., Ltd, and although his interests extended over many fields, it was in the subjects of photometry and illumination that he was peculiarly interested. He was one of the founders of the International Commission on Illumination and was its honotaty secretary for many years.

\section{Middle East Oil}

IN an article. in $\%$ olume 31 , No. 1, of The Lamp (house journal the Standard Oil Co., New Jersey, published fiftimes a year primarily for employees and stod 4 olders) a survey is made of progress in oil prodyctioh during the past fifty years in the Middle East. Turing that time production increased systematicdlly, until in 1948 it reached a total of one million gallons per day, and the area became recognized as the third most important producing centre of the world, the United States and the Caribbean being first and second respectively. The most significant oil region in the Middle East as yet discovered lies in a great geological trough which extends through Iran, Iraq, Saudi Arabia and the smaller sheikhdoms of Kuwait, Bahrein and Quatar. There is intense activity throughout the area, and the very great rise in production is a measure of the success of prolonged labour by oilmen in one of the hottest climates of the world. Nevertheless, Middle East oil could be made to flow faster by elimination of the present bottleneck in transportation. Ninety per cent of the oil is concentrated in the Persian Gulf area, which at the nearest point lies eight hundred miles east and southeast of the Mediterranean. Every barrel of oil travels by sea. The route will probably remain the same for destinations east of Suez; but for the great markets of Western Europe, substitution of overland pipeline transport is geographically feasible. A combined land and sea route of four thousand one hundred miles to the English Channel ports compares impressively with the present all-sea route from the Persian Gulf, south-east round Arabia and northwards through the Red Sea and the Suez Canal. Pipelines when built will, it is estimated, eliminate more than three thousand one hundred miles of tanker haulage on shipments to Western Europe. A map showing proposed pipelines in the Middle East clearly indicates the extent of the project and at the same time demonstrates the present formidable wastage of tanker haulage. Given adequate overland transport facilities, this region can meet all Western European requirements. At the same time, the peoples of the Middle East will begin to feel the benefits attendant upon development of the first mass-volume export complpdity they have ever.had.

Bird Photc

A мEтHOD taking bird photographs which promises to bo great value in the analysis and understandidg of bird flight has been described by Eric Hoskikg (British Birds, 42, No. 8; August 1949) two high-speed electronic flash is many times brigl fer than bright sunlight and is usually arranged to last about $1 / 10,000$ second. 'The set built to produce the flash was made by Dr. P. S. H. Henry, who also devised a photo-cell trip that would automatically operate the camera shutter, and with it the flash, at the instant the bird passed through a pre-arranged zone in front of the camera. With this ingenious apparatus the bird thus takes its own photograph at the moment that it is itself in focus. Mr. Hosking illustrates his article with a number of photographs which have been taken by high-speed electronic flash and suggests that here may well be a means of advancing the study of aeronautics. This new method of photography should certainly add to our knowledge of bird life, and particularly of the more active phases of bird behaviour like courtship and aggressive displays, as well as the identification of food carried in the bill and the recording of feeding behaviour at the nest.

\section{Sources of Information in Great Britain}<smiles>C1=CCCCC1</smiles>

ThE first two ofa series of "Aslib Guides to Sources of Informatipy in Great Britain", issued in pamphlet form suitabl for inclusion in a loose-leaf binder, and intend of cufulatively to form a new edition of the "A Sib Wirectory", have recently been published (No. 1, (T) Paper Industry; pp. ii $+14 ; 2 s .6 d$. net, to mddbers, 2s. No. 2, Agriculture and Allied Interests ; pp. $\mathrm{v}+64 ; 16 s$. net, to members, 13s.). The pamphlets are numbered in accordance with the Universal Decimal Classification and are arranged in three sections dealing with relevant national libraries and loan services, with the organisations in Great Britain which are the main sources of information in the particular field, and with the publications, including periodicals, directories, annuals and yearbooks. They are provided with a subject index to the libraries and other organisations and to the publications listed.

\section{Agricultural Attache to the British Embassy in Buenos Aires}

Mr. A. G.MrLL has been appointed to succeed Major T. A. Rattray as agricultural attaché to the British Embassy in Buenos Aires. Mr. Mill, who is forty-one, has been connected with farming all his life, mainly with cattle, sheep and horses. From 1928 he was for ton years in the Argentine as an estate manager for Liebig's Extract of Meat Co. During the Second World War he was a government livestock officer in Britain, and since 1945 he has served in that capacity in Barbados.

\section{Colonial Service : Recent Appointments}

THe following appointments in the Colonial Service have been recently announced : D. J. O. Burke, A. G. Cullum and A. A. Kingshotte, agricultural officers, Nigerja; I. Constantinesco and A. Hamersley, agricult/ral officers, Tanganyika; J. H. Rhodes and A.T. Wilson, agricultural officers, Northern Rhodesia ; J. Evans and J. A. Sandys, agricultural officers, Nyasaland ; D. W. M. Haynes, agricultural officer, Federation of Malaya; R. H. Forster, agricultural officer, North Borneo; H. Sandford, agricultural officer, Sarawak; E. F. H. Sturgeon, agricultural officer (for soil conservation), Nyasaland; A. G. Bramwell, J. L. Masson, A. J. L. Mitchell and A. L. Roxburgh, assistant conservators of forests, Nigeria; A. P. B. Hamilton, assistant conservator of forests, Northern Rhodesia/Nyasaland; J. R. Hilton, assistant conservator of forests, Uganda; C. S. Kilpatrick, assistant conservator of forests, British Guiana; A. N. Loweth, assistant conservator of forests, Fiji ; I. Paul, assistant conservator of forests, Sierra Leone; M. G. Yearsley, assistant conservator of forests, Gold Coast; O. P. Casey, G. C. McCallum 